\title{
COMPARTIVE STUDY BETWEEN THE EFFECTS OF HUMAN CD34 AND RAT BONE MARROW MESENCHYMAL STEM CELLS ON AMELIORATION OF CCL4 INDUCED LIVER FIBROSIS.
}

Amany O. Mohamed, Naglaa K Idriss ${ }^{1}$ Dina Sabry', Mona Magdy, Hayam G Sayyed ${ }^{4}$, Azza S Abdelrhim 5

\author{
${ }^{1}$ MEDICAL BIOCHEMSITRY AND MOLECULAR BIOLOGY , FACULTY OF \\ MEDICINE, ASSUIT, EGYPT \\ ${ }^{1}$ MEDICAL BIOCHEMSITRY AND MOLECULAR BIOLOGY , FACULTY OF \\ MEDICINE, CAIRO UNIVERSITY \\ ${ }^{3}$ PATHOLOGY DEPARTMENT, THEODOR BILHARZIA RESEARCH \\ INSTITUTE, GIZA, EGYPT. \\ ${ }^{4}$ FACULTY OF MEDICINE, ASSUIT, EGYPT \\ ${ }^{5}$ ANATOMY DEPARTMENT, FACULTY OF MEDICINE, SOHAG \\ UNIVEERSITY, SOHAG
}

Received 10/5/2015 - Accepted 20/6/2015

\begin{abstract}
Human umbilical cord blood (UCB) cells and rat bone marrow mesenchymal stem cells (BM-MSCs) have many advantages as grafts for cell transplantation. The aim of this study was to investigate the impact of UCB cells and BM-MSCs on reversal of hepatic injury and revival of hepatic function in a rat model of carbon tetrachloride $\left(\mathrm{CCl}_{4}\right)$-induced liver fibrosis.
\end{abstract}

Keywords: $\mathrm{CCl}_{4}$ liver fibrosis, Umbilical cord blood $\mathrm{CD} 34^{+}$, Bone marrow stem cell, Stem cell therapy.

Stem cells administration recovered liver function that confirmed by histopathological examination of liver tissue. GFP labeled cells were detected in groups injected with stem cells. Concerning gene expression, stem cells administration reduced gene expressions of collagen $1 \alpha$, TGF- $\beta 1$, and TNF- $\alpha$ with lower expression in $\mathrm{CCl}_{4} / \mathrm{CD} 34^{+}$group. Albumin, MMP-2 and MMP-9 genes were highly

34

* Correspondence Author (e mail: : amanyosama@yahoo.com) 
expressed in liver tissues in the groups that received stem cells with higher expression in the group that received undifferentiated CD $34^{+}$.

Human UCB CD34 ${ }^{+}$stem cells were more effective in alleviation of $\mathrm{CCl}_{4}$-induced liver injury in rat than BM-MSCs. This study highlights an important role of human $\mathrm{UCB} \mathrm{CD} 4^{+}$stem cells in liver fibrosis therapy.

\section{INTRODUCTION}

Liver fibrosis is a progressive disease that included disorder of standard hepatic tissue construction in addition to tremendous accretion of extracellular matrix in reply to chronic damage (Nasir et al., 2013). Inflammation is compulsory to originate and conserve of liver fibrosis. As soon as grievance turn up, scratched epithelial and/or endothelial cells ooze inflammatory mediators that draw inflammatory cells from the blood to the offended area and release mediators that persuade fibrosis such as TGF- $\beta 1$ and TNF- $\alpha$, turn on hepatic stellate cells and gather extracellular matrix (Zheng et al.,2013). Besides, collagens, the main protein of connective tissues, correspond to a group of obviously occurring proteins, and comprising $25-35 \%$ of the total body protein. It is conventional in liver fibrosis that there is tremendous collagen creation (El-Mahdi., 2014). As fibrotic liver diseases advancement, disease advanced from collagen bands to bridging fibrosis subsequently to frank cirrhosis. Extracellular matrix (ECM) declaration resulted from increased synthesis as well as decreased degradation that due to decreased ECM removing matrix metalloproteinases (MMPs) activity (Puglisi., 2011\& Radwa.,2012). Liver transplantation has been used in the management of liver fibrosis. Nonetheless, the escalating number of patients and insufficient availability of donors, morbidity and mortality from liver fibrosis continue to be increased. Consequently, alternative therapies are immediately required. Mesenchymal stem cells (MSCs) have involved attention as a possible cell source for repair of damaged liver (Kanazawa et al., 2011 \& Xu et al., 2012). Recently, stem cells, undifferentiated cells, hold promising therapeutic results since they undergo self- renewal and differentiation into one or more cell types, and are appropriate to human disorders(Abdel Aziz et al., 2014). Umbilical cord blood (UCB) contained mostly hematopoietic stem cells (HSCs)(De Coppi et al.,2007) .The stem cells and early progenitors expressed CD34, a surface membrane glycoprotein, and is 
the characteristic of HSPCs. The bulk of CD $34^{+}$cells expressed HLADR (a major histocompatibility complex class II) and CD38 (a surface antigen on leukocytes) antigens. The number of CD34 ${ }^{+} \mathrm{HLADR}^{-}$and $\mathrm{CD} 34^{+} \mathrm{CD} 38^{-}$cells in $\mathrm{UCB}$ is greater than in adult bone marrow (BM). Thus, UCB contains a higher amount of immature HPCs than adult BM (Radwa et al., 2012). In bone marrow (BM) there are several populations of stem cell including hematopoietic stem cells (HSCs), marrow mesenchymal stem cells (MSCs), and multi-potent adult progenitor cells. Many authors accounted that $\mathrm{CD}^{+} 4^{+}$cells and BM-MSC could assuage chemically-induced liver fibrosis(Abdel Aziz et al., 2014), however, which cell type is more effective in alleviating liver fibrosis and the mechanism by which MSC repair the fibrosis is unclear and their results seem notorious. In the present study, we employed an experimental model of liver fibrosis induced with $\mathrm{CCl}_{4}$ and compared between the ameliorative effects of human $\mathrm{CD} 34^{+}$and rat bone marrow derived mesenchymal stem cells on functional revival of the liver and management of injury in a rat model of hepatic fibrosis. Also, we studied the mechanism that induces the protective activity of stem cells by examining the expression of key genes in the pathogenesis of hepatic fibrosis such as collagen-1-alpha, transforming growth factor beta (TGF $\beta 1$ ), matrix metalloproteinase (MMP-2), MMP-9, and tumor necrosis factor-alpha (TNF- $\alpha$ ) by realtime PCR. Here, we transplanted UCB cells and BM-MSCs into injured liver fibrosis and investigated the reversal of hepatic fibrosis after in vivo transplantation.

\section{MATERIALS AND METHODS}

Experimental Animals: Forty female white Albino rats were 6 weeks old, weighing between 150 and $200 \mathrm{~g}$. Rats were bred and maintained in an air-conditioned animal house with specific pathogenfree conditions. All experimental animals have ethical approval from the institutional animal care committee. They were subjected to a normal light/dark cycle and allowed unlimited access to chow and water. All experimental protocols followed the guidelines of the Animal Committee of the Faculty of Medicine of Assiut University.

Induction of Liver Fibrosis: Liver fibrosis was induced by subcutaneous injection of carbon tetrachloride $\left(\mathrm{CCl}_{4}\right)$ at a dose of 0.2 $\mathrm{ml} / 100 \mathrm{~g}$ body weight of $40 \mathrm{ml} / \mathrm{L} \mathrm{CCl}_{4}$ (Sigma, St Louis, USA) dissolved in equal volume of castor oil (Sigma, St. Louis, USA). The 
injection was given twice weekly for 6 weeks (Zhao., et al 2005).

Experimental Design Rats were divided into the following groups:

Control group 1: 10 rats received $0.2 \mathrm{ml} / 100 \mathrm{~g}$ body weight of castor oil twice weekly for 6 weeks. $\mathrm{CCl}_{4}$ group 2: 10 rats received $0.2 \mathrm{ml} / 100$ $\mathrm{g}$ body weight of $\mathrm{CCl}_{4}$. Liver fibrosis was determined by histopathological examination. $\mathrm{CCl}_{4} / \mathrm{CD} 4^{+}$group 3: 10 rats received $\mathrm{CCl}_{4}$ as previous. The rats were infused with $10^{7}$ isolated $\mathrm{CD}_{4} 4^{+}$cells/rat intravenously (through tail vain) and scarified after 3 months. $\mathrm{CCl}_{4} / \mathrm{BM}-\mathrm{MSC}$ group 4:, 10 rats received $\mathrm{CCl}_{4}$ as previous and followed by injection of $10^{7} \mathrm{BM}-\mathrm{MSCs}$ and scarified after 3 months.

At 4,8 and 12 weeks from stopping $\mathrm{CCl}_{4}$ and administration of stem cells, venous blood was collected from the retro-orbital vein to assess serum albumin and alanine transaminase (ALT). All rats were sacrificed with $\mathrm{CO}_{2}$ narcosis, and liver tissue was harvested for histopathological examination and real time PCR analysis.

Isolation and Culture of BM-MSCs: Bone marrow cells were flushed from tibia and fibula of rat bones with phosphate-buffered saline (PBS) containing $2 \mathrm{mM}$ EDTA. Over $15 \mathrm{ml}$ Ficoll-Paque (GibcoInvitrogen, Grand Island, NY), $35 \mathrm{ml}$ of the diluted sample was carefully layered, centrifuged for 35 minutes at $400 \mathrm{xg} \mathrm{rpm}$ and the upper layer was aspirated leaving undisturbed mononuclear cell (MNC) layer at the interphase. This MNC layer was aspirated, washed twice in PBS containing $2 \mathrm{mM}$ EDTA and centrifuged for 10 minutes at $200 \mathrm{xg} \mathrm{rpm}$ at $10{ }^{\circ} \mathrm{C}$. The cell pellet was re-suspended in a final volume of $300 \mu \mathrm{l}$ of buffer. Isolated MSCs were cultured on $25 \mathrm{ml}$ culture flasks in minimal essential medium(MEM) supplemented with $15 \%$ fetal bovine serum (FBS) and incubated for 2 hours at $37^{\circ} \mathrm{C}$ and $5 \% \mathrm{CO}_{2}$. Adherent MSCs were cultured in MEM supplemented with $30 \% \mathrm{FBS}, 0.5 \%$ penicillin, streptomycin and at $37^{\circ} \mathrm{C}$ in $5 \% \mathrm{CO}_{2}$ in air (Abdel Aziz., et al 2007). Cultured MSCs was confirmed by morphology (Fig. 1) and Florescent Analysis Cell Sorting (FACS) by detection of $\mathrm{CD} 29^{+}$and $\mathrm{CD} 44^{+}$specific to MSCs (Fig. 2).

Collection of Human Umbilical Cord Blood: Human umbilical cord blood withdraws immediately after normal vaginal delivery within 24 hours after rupture of membranes and before separation of the placental. Written informed consent was obtained from each woman after a full explanation of the study. Ethical standard approval was 
maintained throughout the present work. Participants considered suitable for the study according to the following exclusion and inclusion criteria.Women with the following criteria were excluded: Family history of gene based disorders or maternal fever during delivery. The umbilical cord clamped one inch or less apart at the infant's abdomen. Umbilical cord was sterilized with $70 \%$ alcohol followed by betadine at the needle insertion site. The needle inserted just above the clamp. Blood allowed pouring as much as possible. The collection normally took about 3-5 minutes.

Cell Sorting of Human UCB CD34 ${ }^{+}$: Anti-coagulated human umbilical cord blood (UCB) was diluted 1:4 with PBS containing 2 mM EDTA (Gibco-Invitrogen, Grand Island, NY). As prescribed in our previous work [12]. Briefly, the MNCs were separated by centrifugation over a Ficoll-Paque (Gibco-Invitrogen, Grand Island, $\mathrm{NY}$ ) density gradient at $400 \mathrm{xg}$ rpm for 35 minutes at $10^{\circ} \mathrm{C}$. The $\mathrm{MNC}$ fraction was washed first in PBS, then with MACS (magnetic cell sorting) buffer (PBS supplemented with $0.5 \%$ bovine serum albumin and $2 \mathrm{mM}$ EDTA, $\mathrm{pH}$ 7.2). $\mathrm{CD} 34^{+}$cells were isolated from MNCs, using the $\mathrm{CD}^{2}{ }^{+}$positive cell selection kit (MiniMacs; Miltenyi Biotec, Bergisch Gladbach, Germany). Percentage of isolated CD34 ${ }^{+}$ cells was characterized by flow cytometry.

Labeling Stem Cells with GFP: At $4^{\text {th }}$ passage, MSCs were harvested and labeled with GFP (amaxa GmbH, amaxa Inc. Europe/World USA Scientific Support). Human MSC were nucleofected using the Human MSC Nucleofector Kit and a plasmid encoding the fluorescent protein GFP. Cells were centrifuged, washed twice in serum free medium, pelleted and suspended in nucleofector solutions. A final concentration of $4-5 \times 10^{5}$ cells/ $100 \mu l$ nucleofector solutions was applied. The sample was placed in cuvette of elactroporation transfection instrument at program U-23 (for high transfection efficiency) or C-17 (for high cell survival). 24 hours postnucleofection cells were analyzed by light and fluorescence microscopy.Transfection efficiencies of around $80 \%$ can be reached with GFP. Labeled cells were injected intravenously in rat with $\mathrm{CCL}_{4}{ }^{-}$ induced liver fibrosis. After 12 weeks, liver tissue was examined with a fluorescence microscope (Leica, Germany) to detect and trace the cells stained with GFP.

Serum Biochemical Assessment: Blood sample was driven from rats 
at 4, 8 and 12 weeks. ALT and albumin were assessed using (Randox laboratories limited, Country Antrim, UK) colorimeter kits according to manufacture instructions.

Histopathological Examination: Liver tissues were collected and divided into two sections. The first section was assessed for tracing of injected labeled cells with GFP. The second section was washed with PBS and fixed overnight in $40 \mathrm{~g} / \mathrm{L}$ paraformaldehyde at $4^{\circ} \mathrm{C}$. Serials $\mu \mathrm{m}$ sections of the dissected liver tissues were stained with hematoxylin and eosin (H\&E) and Masson Trichrome for evaluation of fibrosis.

Immunohistochemistry: Immunohistochemical staining was performed on $5-\mu \mathrm{m}$, formalin-fixed, paraffin-embedded sections using the CD34 \& Albumin antibodies at 1:50 dilution (DAKO, Carpinteria, $\mathrm{CA}$ ). Antigen retrieval was performed in all cases by steam heating the slides in a 1-mmol/L solution of EDTA ( $\mathrm{pH} \mathrm{8.0)} \mathrm{for} 30$ minutes. After blocking of endogenous biotin, staining was performed using an automated immunostainer (DAKO) followed by detection by using a streptavidin-biotin detection system (DAKO). Positive and negative control sections were used for each assay.

RNA Extraction: Liver tissue of all studied groups was homogenized and total RNA was isolated with RNAeasy Mini Kit (Qiagen) and further analyzed for quantity and quality with Beckman dual spectrophotometer (USA). Real Time PCR (qRT-PCR) for Quantitative Expression of Collagen I $\alpha$, TGF- $\beta$, Albumin, MMP-2 and 9 and TNF- $\alpha$.

The mRNA expression level was quantified by qRT-PCR (Real time PCR). $1000 \mathrm{ng}$ of the total RNA from each sample were used for cDNA synthesis by reverse transcription using High capacity cDNA Reverse Transcriptase kit (Applied Biosystem, USA). The cDNA was subsequently amplified with the Syber Green I PCR Master Kit (Fermentas) in a 48-well plate using the Step One instrument (Applied Biosystem, USA) as follows: 10 minutes at $95{ }^{\circ} \mathrm{C}$ for enzyme activation followed by 40 cycles of 15 seconds at $95^{\circ} \mathrm{C}, 20$ seconds at $55^{\circ} \mathrm{C}$ and 30 second at $72{ }^{\circ} \mathrm{C}$ for the amplification step. Changes in the expression of each target gene were normalized relative to the mean critical threshold (CT) values of GAPDH housekeeping gene by the $\Delta \Delta \mathrm{Ct}$ method. We used $1 \mu \mathrm{M}$ of both primers specific for each target gene. Primers sequence and annealing temperature specific for each gene demonstratedin Table (1). 


\section{Statistical analysis}

The collected data was organized, tabulated and statistically analyzed using prism software statistical computer package version 5. Mean and standard deviation were calculated; one-way ANOVA (Analysis of variance) was used to test the difference about mean values of measured parameters among groups. For interpretation of results of tests of significance, significance was adopted at $\mathrm{P}<0.05$.

\section{RESULTS}

BM -MSCs showed positive expression of the $\beta 1$-integrin CD29 and the endoglin receptor CD44 in Figure $1(\mathbf{a}, \mathbf{b})$. Liver function was monitored by the serum level of albumin and alanine aminotransferase (ALT) as displayed in Figure 2. At the end of the $1^{\text {st }}$ month, both $\mathrm{CCl} 4 / \mathrm{CD}_{3} 4^{+}$and $\mathrm{CCl}_{4} / \mathrm{BM}-\mathrm{MSCs}$ groups showed non-significant increase in the serum level of albumin as compared to the $\mathrm{CCl}_{4}$ group. At the $2^{\text {nd }}$ and $3^{\text {th }}$ months, serum level of albumin in rats injected with CD34 ${ }^{+}$and BM-MSCs increased significantly as compared to $\mathrm{CCl}_{4}$ group $(\mathrm{P}<0.001)$. Highest level was demonstrated in the $\mathrm{CCl}_{4} / \mathrm{CD} 34^{+}$ group but there was non-significant difference with $\mathrm{CCl}_{4} / \mathrm{BM}-\mathrm{MSC}$ group. Regarding to the liver enzymes, ALT, at the $1^{\text {st }}$ month there was non-significant reduction of its level in $\mathrm{CCl}_{4} / \mathrm{CD} 34^{+}$or $\mathrm{CCl}_{4} / \mathrm{BM}$ MSCs groups as compared to the $\mathrm{CCl}_{4}$ group. At $2^{\text {nd }}$ and 3 th months, serum level of ALT showed significant decrease in comparison to the $\mathrm{CCl}_{4}$ group $(\mathrm{P}<0.001)$. However, its level was still significantly higher than control level and there was no significant difference between the groups that received stem cells. Concerning gene expression, the rat collagen $1 \alpha$, TGF- $\beta$ and TNF- $\alpha$ gene were highly expressed in $\mathrm{CCl}_{4}$ group and expression of collagen $1 \alpha$ was significantly decreased after stem cells administration. Least expression was in the $\mathrm{CCl}_{4} / \mathrm{CD} 34^{+}$group. However, there was no significant difference between the different groups that received stem cells. Whereas, TGF- $\beta$ was still significantly expressed in $\mathrm{CCl}_{4} / \mathrm{CD} 34^{+}$ and $\mathrm{CCl}_{4} / \mathrm{BM}-\mathrm{MSCs}$ groups $(\mathrm{P}<0.05$ and $\mathrm{P}<0.001$, respectively). As regard to gene expressions of albumin, MMP-2 and MMP-9. They were expressed in liver tissues in the groups that received stem cells but the expressions not reach a significant level in MMP genes. Highest expression was in $\mathrm{CCl}_{4} / \mathrm{CD} 34^{+}$group (Table3). Histopathological examination of liver tissue showed that stem cells 
have a significant anti-fibrotic effect as evidenced by the decrease in liver collagen compared to the $\mathrm{CCl}_{4}$ group together with improvement of liver histopathological picture as detected by Hematoxylin \& Eosin and Masson Trichome (Figure 3). Albumin is normally expressed by hepatocytes indicating functioning hepatocytes. It exhibits cytoplasmic expression. Bile ducts \& portal mononuclear cells don't express albumin. In this study, albumin expressing cells was detected in the portal areas indicating differentiation of injected BM-MSCs and CD34 ${ }^{+}$cells into hepatocytes (Figure 4).

Table (1): Primers sequenceand annealing temperature specific for each gene

\begin{tabular}{|c|c|c|}
\hline $\begin{array}{l}\text { Target } \\
\text { gene }\end{array}$ & Primer sequence: 5 - 3 & $\begin{array}{l}\text { Gene bank } \\
\text { accession } \\
\text { number }\end{array}$ \\
\hline $\begin{array}{r}\text { Collagen } \\
\text { I } \alpha\end{array}$ & $\begin{array}{c}\text { Forward: } \\
\text { AGAGCATGACCGATGGATTC } \\
\text { Reverse: CCTTCTTGAGGTTGCCAGTC }\end{array}$ & KJ696743.1 \\
\hline Albumin & $\begin{array}{c}\text { Forward: } \\
\text { TTTACGAGAAGCTTGGAGAG } \\
\text { Reverse: } \\
\text { TGTGCAGATATCAGAGTGGA }\end{array}$ & FQ210445.1 \\
\hline TGF- $\beta$ & $\begin{array}{c}\text { Forward: } \\
\text { TGCGCCTGCAGAGATTCAAG } \\
\text { Reverse: } \\
\text { AGGTAACGCCAGGAATTGTTGCTA }\end{array}$ & NM_021578.2 \\
\hline MMP-2 & $\begin{array}{l}\text { Forward: CTATTCTGTCAGCACTTTGG } \\
\text { Reverse: CAGACTTTGGTTCTCCAACTT }\end{array}$ & NM_031054.2 \\
\hline MMP-9 & $\begin{array}{l}\text { Forward: AAATGTGGGTGTACACAGGC } \\
\text { Reverse: TTCACCCGGTTGTGGAAACT }\end{array}$ & NM_031055.1 \\
\hline TNF- $\alpha$ & $\begin{array}{c}\text { Forward:AACTCGAGTGACAAGCCCGTAG } \\
\text { Reverse: } \\
\text { GTACCACCAGTTGGTTGTCTTTGA }\end{array}$ & $\begin{array}{c}\text { XM_0087727 } \\
75.1\end{array}$ \\
\hline GAPDH & $\begin{array}{c}\text { Forward : } \\
\text { CACCCTGTTGCTGTAGCCATATTC } \\
\text { Reverse: } \\
\text { GACATCAAGAAGGTGGTGAAGCAG }\end{array}$ & XR_598347.1 \\
\hline
\end{tabular}


Table (2): Effects of human $\mathrm{CD34}^{+}$and rat bone marrow mesenchymal stem cells on the gene expression of collagen $1 \alpha$, TGF- $\beta$, albumin, MMP-2, MMP-9 and TNF- $\alpha$ in $\mathrm{CCl}_{4}$-induced liver fibrosis in rats

\begin{tabular}{|c|c|c|c|c|}
\hline $\begin{array}{l}\text { Groups } \\
\text { Parameters }\end{array}$ & $\begin{array}{c}\begin{array}{c}\text { Group 1 } \\
\text { (Control } \\
\text { group) } \\
\mathbf{n}=\mathbf{1 0}\end{array}\end{array}$ & $\begin{array}{c}\text { Group } 2 \\
\text { (CCL4 } \\
\text { group) } \\
\text { n=10 }\end{array}$ & $\begin{array}{c}\text { Group 3 } \\
\left(\mathrm{CCl}_{\mathbf{4}} / \mathrm{CD34} 4^{+}\right. \\
\text {group) } \\
\mathbf{n}=\mathbf{1 0}\end{array}$ & $\begin{array}{c}\text { Group 4 } \\
\text { (CCl } / \text { BM- } \\
\text { MSCs } \\
\text { group) } \\
\text { n =10 }\end{array}$ \\
\hline Albumin gene & $\begin{array}{c}3.85 \pm \\
1.06\end{array}$ & $\begin{array}{c}0.89 \pm \\
0.35^{* * *}\end{array}$ & $\begin{array}{c}2.93 \\
\pm 0.85 \dagger \dagger \dagger\end{array}$ & $\begin{array}{c}1.88 \pm \\
0.71 * * * \dagger\end{array}$ \\
\hline $\begin{array}{l}\text { Collagen } 1 \alpha \\
\text { gene }\end{array}$ & $\begin{array}{c}0.33 \pm \\
0.14\end{array}$ & $\begin{array}{c}1.81 \pm \\
0.63 * * *\end{array}$ & $\begin{array}{c}0.62 \pm \\
0.21+\dagger \dagger\end{array}$ & $\begin{array}{c}0.76 \pm \\
0.33+\dagger \dagger\end{array}$ \\
\hline TGF- $\beta$ gene & $\begin{array}{c}0.21 \pm \\
0.09\end{array}$ & $\begin{array}{c}1.08 \pm \\
0.39 * * *\end{array}$ & $0.59 \pm 0.26^{*}$ & $\begin{array}{c}0.81 \pm \\
0.26^{* * *}\end{array}$ \\
\hline MMP-2 gene & $\begin{array}{c}1.46 \pm \\
0.68\end{array}$ & $\begin{array}{l}0.70 \pm \\
0.27 *\end{array}$ & $1.09 \pm 0.50$ & $0.93 \pm 0.51$ \\
\hline MMP-9 gene & $\begin{array}{c}1.63 \pm \\
0.49\end{array}$ & $\begin{array}{c}0.77 \pm \\
0.27 * * *\end{array}$ & $1.12 \pm 0.50$ & $\begin{array}{l}1.00 \pm \\
0.37^{*}\end{array}$ \\
\hline TNF- $\alpha$ gene & $\begin{array}{c}1.03 \pm \\
0.55\end{array}$ & $\begin{array}{l}1.66 \pm \\
0.36 * *\end{array}$ & $\begin{array}{c}0.93 \pm \\
0.22+\dagger \dagger\end{array}$ & $\begin{array}{c}0.93 \pm \\
0.32+1 \dagger\end{array}$ \\
\hline
\end{tabular}

Data were expressed as mean \pm SD. TGF- $\beta$ : Transforming growth factor-beta, MMP-2: Matrix metalloproteinase-2, MMP-9: Matrix metalloproteinase-9, TNF- $\alpha$ : Tumor necrosis factor-alpha. Analysis between groups was done using one way ANOVA test followed by Bonferroni test. *: $\mathrm{P}<0.05$ and $* * *: \mathrm{P}<0.001$ compared to the control group; $\uparrow: \mathrm{P}<0.05$, $\uparrow \uparrow \uparrow: \mathrm{P}<0.001$ compared to the $\mathrm{CCl} 4$ group. 


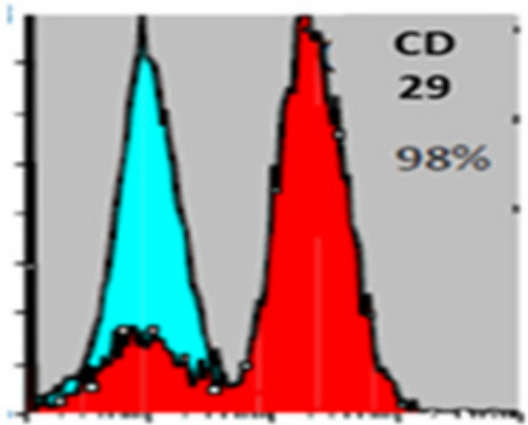

FL2 Loa

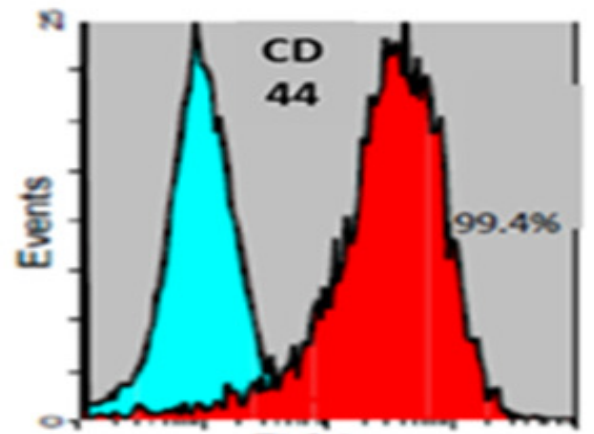

FL2 Loa

Figure (1): Rat BM-MSCs at one week of culture (a), rat

A

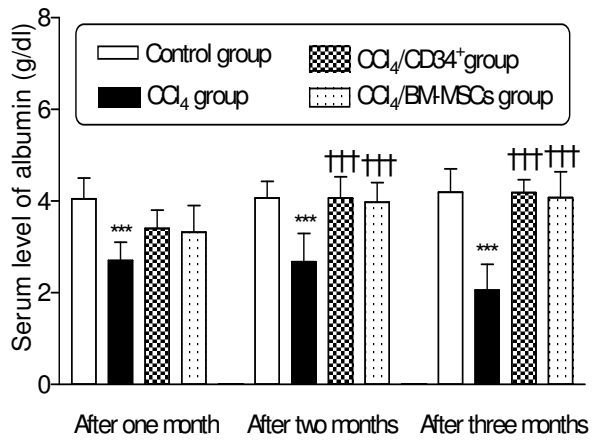

B

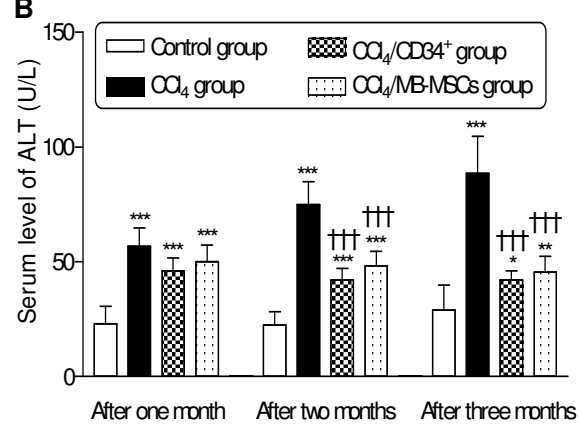

BM-MSCs at two weeks of culture (80-90\% confluent) (b)

Figure (2): Effects of human $\mathrm{CD}_{3} 4^{+}$and rat bone marrow mesenchymal stem cells on the serum level of albumin and ALT in CCl4-induced liver fibrosis in rats. Data were expressed as mean \pm SD. LH: ALT: alanine transaminase. Analysis between groups was done using one way ANOVA test followed by Bonferroni test. *: $\mathrm{P}<0.05$, **: $\mathrm{P}<0.01$, and ***: $\mathrm{P}<0.001$ compared to the control group; $+\dagger \dagger: \mathrm{P}<0.001$ compared to the $\mathrm{CCl} 4$ group. 

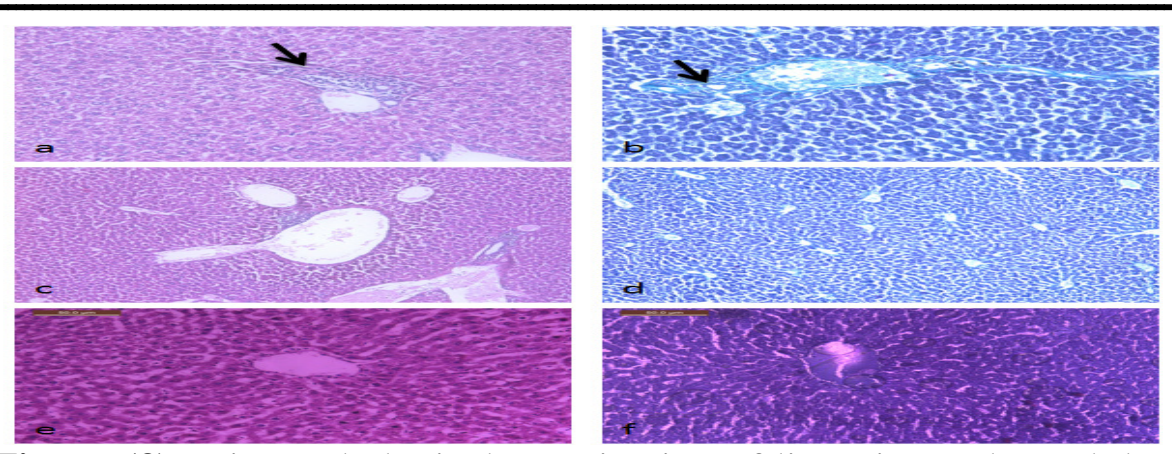

Figure (3): Histopathological examination of liver tissue showed that stem cells have a significant antifibrotic effect as evidenced by the decrease in liver collagen compared to the $\mathrm{CCl}_{4}$ group. Mild focal portal fibrosis was detected in $\mathrm{CCl}_{4}$ model (black arrow) a-H\&E x200 and $b$ - Masson Trichrome $\mathrm{x} 200$. Normal liver was evidenced with no fibrosis after BM-MSCs injection in $\mathrm{CCl}_{4}$ model c- $\mathrm{H} \& \mathrm{E} \times 40$ and dMasson Trichrome $\mathrm{x} 40$. Normal liver was assessed showed no fibrosis $\mathrm{CD}_{3}{ }^{+}$injection in $\mathrm{CCl}_{4}$ model e- $\mathrm{H} \& \mathrm{E}$ x200 and $\mathrm{f}-$ Masson Trichrome $\mathrm{x} 200$.
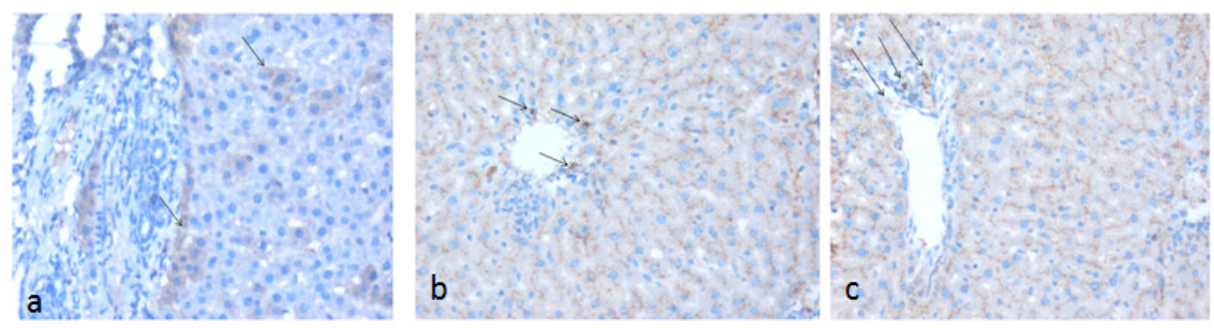

Figure (4): a-Showed immunohistochemistry (400x) positive expression of $\mathrm{CD}_{3} 4^{+}$differentiated hepatocytes in portal area (arrow). Some hepatocytes showed expression of CD34 positivity around portal tract. b- Showed immunohistochemistry (400x) positive expression of albumin for injected BM-MSCs in portal area (arrows). c- Showed immunohistochemistry (400x) positive expression of albumin for injected $\mathrm{CD}^{+} 4^{+}$in portal area (arrows).

\section{DISCUSSION}

Owing to a grave scarcity of liver donors and the high-risk of transplant rejection, a surrogate therapeutic approach is advantageous for patients with liver failure.Stem cell therapy demonstrated a great talented outcome for repair of tissues and organs injury, together with the liver. Stem cells are undifferentiated cells that have the capability 
to self-renewal and multi-lineage differentiation (Abdel Aziz et al., 2014). Accordingly, the present study compared the ability of human $\mathrm{CD}^{+}{ }^{+}$and rat BM-MSCs injection to ensure the functional revival of the liver and improvement of fibrosis in an experimental model of liver fibrosis in rats induced by $\mathrm{CCl}_{4}$.

The chief findings of this study were: 1) both human umbilical cord blood derived $\mathrm{CD}_{3} 4^{+}$and rat bone marrow-derived MSCs improved liver function in rats with $\mathrm{CCl}_{4}$-induced liver fibrosis as indicated by increased serum albumin and decreased ALT levels and this confirmed by histopathological assessment of liver tissue. 2) Administration of human $\mathrm{CD}_{3} 4^{+}$stem cells more effectively decreased collagen $1 \alpha$, TGF $\beta 1$ and TNF- $\alpha$ and increased albumin, MMP-2, and MMP-9 gene expression than bone marrow-derived MSCs. In contrast to BM-MSCs, UCSCs have higher division, homing, differentiation and extension opportunity and susceptibility to genetic treatment, and they create a lesser frequency of graft-vs.-host disease (Sáez-Lara et al., 2006). In the present study, injection of human $\mathrm{CD}_{34}{ }^{+}$and rat BM-MSCs increased albumin and decreased ALT levels in the serum and this indicated normalization of liver function with stem cells injection. In agreement with the present results, Abdel Aziz et al.2012, showed that human $\mathrm{CD} 34^{+}$cells derived from human UCB capable to recover liver purpose as indicated by increasing serum albumin and decreasing ALT level in rats with liver fibrosis. Also, intravenously infused BM-MSCs resulted in upgrading of liver functions (Abdel Aziz et al., 2012 and Zhao et al .,2012). This occurred concurrently with increased albumin gene expression with higher expression with human $\mathrm{CD} 34^{+}$cells injection. This is consistent with the finding of Abdel Aziz et al., 2012. who's found increased albumin gene expression in liver tissues in the group that received human $\mathrm{CD} 34^{+}$stem cells. Also, Ali and Masoud ., 2012, demonstrated a marked increase in the albumin gene expression after transplantation of BM-MSCs. The ability of stem cells to recover liver function in rats with $\mathrm{CCl}_{4}$-induced liver fibrosis was long-established by histopathological examination of liver tissue. Treatment with human $\mathrm{CD} 34^{+}$and rat BM-MSCs showed a return of liver design to normal and anti-fibrotic effect as evidenced by the decrease in liver collagen compared to the $\mathrm{CCl}_{4}$ group together with upgrading of liver histopathological picture. The recognized reduction 
in the liver fibrosis might contribute to inhibition of collagen formation or breakdown of collagen. Many researchers observed the anti-fibrotic effect of BM-MSCs through embarrassment of collagen formation and they speculated that BM-MSCs have an effective therapeutic effect against fibrosis (El-Mahdi et al.,2014; Abdel Aziz., et al ., 2014 and Abdel Aziz., et al ., 2007). Moreover, Hong et al.,2014, observed that human UCBMSCs capable to recover liver cirrhosis by breaking down collagen fibers. TGF $\beta 1$ is believed to be the key fibrogenic cytokine in liver fibrosis that plays a noteworthy role in the metabolism of ECM (Hong et al.,2014, Crosby et al., 2009; Hernandez-Gea et al.,2011 and Mannaerts et al ., 2013). Augmented expression of TGF $\beta 1$ related to HSCs commencement and ECM deposition during initiation and progression of fibrosis (Hong et al., 2014). Besides, collagens are the major constituents of the ECM. Collagen $1 \alpha$, another pro-fibrotic factor produced by activated hepatic stellate cells, is a significant indicator of collagen metabolism in the liver(Ali and Masoud., 2012). The tendency in gene expression levels of TGF- $\beta 1$ paralleled those of collagen $1 \alpha$ (Presser et al ., 2013). Our results are consistent with those in humans and mammalian models in which increased gene expression of collagen and collagen deposition in liver fibrosis be an adjunct to increased TGF- $\beta 1$ gene expression (Presser et al ., 2013 and Li et al., 2013). In the present study, we found that treatment of $\mathrm{CCl}_{4}$-induced rat liver fibrosis with stem cells resulted in a marked reduction in the gene expression levels of pro-fibrogenic factors, including collagen $1 \alpha$ and TGF- $\beta 1$ with higher reduction in $\mathrm{CCl}_{4} / \mathrm{CD} 34^{+}$group. This is in accordance to a study conducted by Ali and Masoud., 2012 who's found reduction of collagen I $\alpha$ gene expression after 4 weeks of bone marrow derived MSCs transplantation in comparison with $\mathrm{CCl}_{4}$ treated group. Also, $\mathbf{L i}$ et al., 2013, who's demonstrated successful reduction of TGF- $\beta 1$ level in serum after transplantation of human umbilical cord MSCexosomes into mouse liver fibrosis induced with $\mathrm{CCl}_{4}$. MMP-2 is secreted by HSCs (Li et al ., 2013), it degrades collagen IV, a chief constituent of the vascular basement membrane (Gressner et al., 2002 and Li et al ., 2013). MMP-9 help migration of bone marrow derived MSCs to the site of inflammation (Ali and Masoud ., 2012). The results of the current study showed that administration of stem cells reduced gene expression of MMP-2 and MMP-9 with higher expression in $\mathrm{CCl}_{4} / \mathrm{CD} 34^{+}$group. This is consistent with the finding of 46 
Abdel Aziz et al., 2010, who's found enhanced MMP-2 gene expression in liver tissues in the group that received human $\mathrm{CD} 34^{+}$ stem cells. Also, Li et al., 2013, observed that combined treatment liver fibrosis with taurine, epigallocatechin gallate and genistein resulted in marked increase in the expression of MMP-2 in the HSC cells. During progression of liver fibrosis diverse cytokines, chemokines and growth factors are secreted as part of the inflammatory reaction (Van Wettere et al., 2013). Furthermore TNF$\alpha$ is a pro-inflammatory cytokines produced basically by macrophages (Zhou et al., 2014 and $\mathrm{Li}$ et al., 2013). In the present study, administration of human $\mathrm{CD}^{+} 4^{+}$and BM-MSCs stem cells similarly reduced TNF- $\alpha$ gene expression. This effect claimed to antiinflammatory and immunosuppressive properties of MSCs. This is in accordance with the finding of Huang et al.2014., who's revealed that co-culture of MSC with neuron deprived from oxygen and glucose alleviated neuronal recovery with decreasing TNF- $\alpha$. Moreover, MSCs administration were effective in decreasing the level of TNF- $\alpha$ and treating antigen-induced arthritis in mice (Kehoe et al., 2014) and sheep model of osteoarthritis (Song et al.,2014).

Wang et al.,2014 demonstrated that human albumin RNA was detected specifically in the livers of the mice that had received $\mathrm{CCl}_{4}$ injury, but not in other tissues such as spleen and BM. The human albumin-expressing cells, stained blue, were found to be dispersed throughout some areas of the liver. Normally albumin is expressed by hepatocytes indicating a functioning hepatocytes .it exhibits cytoplasmic expression. Bile ducts \& portal mononuclear cells don't express albumin. In this study, albumin expressing cells were detected in the portal areas indicating that injected stem cells were transdifferentiated in both $\mathrm{CD} 34^{+}$ve and BM-MSCs groups into functioning mature hepatocytes indicated by immunohistochmistry. Crosby et al., 2009, have shown that c-kit and CD $34^{+}$positive cells isolated from human liver are able to differentiate into biliary epithelial cells and endothelial cells. Thus, biliary cells and endothelial cells may also share some common precursors. Additionally, some antigens traditionally associated with hematopoietic cells (c-kit and $\mathrm{CD} 34^{+}$) can also be expressed by oval cells. Our study showed positive staining $\mathrm{CD}^{+} 4^{+}$differentiated injected stem cells in portal area and this explain that oval cells gradually transform themselves into small basophilic hepatocytes, 
which then become fully mature hepatocytes and replace the lost liver mass. Thus, the precursor-product relationship between oval cells and basophilic hepatocytes has been proved in our study. Furthermore the adhesion of human haematopoietic (CD34+) stem cells to human liver compartments is integrin and CD44 dependent and modulated by CXCR3 and CXCR4. Barely is the form of liver injury probable to be significant in settling on which stem cell repair mechanism is triggered, although it is also likely to control how hastily liver repair or reconstitution arises.

Our work advocates that in chronic liver injury models, liver repair is a slow process and may take more than 6 weeks. Cells conscripted to the site of regeneration may need to reveal a survival growth advantage over the endogenous liver cells that are affected by the disease process. In conclusion, the present study revealed that human $\mathrm{CD}_{3}{ }^{+}$is more effective in amelioration of $\mathrm{CCl}_{4}$-induced liver injury in rat than BM-MSCs by reducing fibrosis, expressing liver-specific genes, decreasing gene expression of pro-fibrotic genes (collagen $1 \alpha$ and TGF $\beta 1$ ), and increasing anti-fibrotic genes (MMP-2, MMP-9 and TNF- $\alpha$. This work also confirm long term safety efficacy of human cord blood $\mathrm{CD}_{3} 4^{+}$and potential therapeutic abilities of these cells provided by higher significant synthetic function of $\mathrm{CD} 34^{+}$for albumin compared to BM-MSCs.

Acknowledgement: This work was funded by a grant from Faculty of medicine Assuit University.

Conflict of interest: All authors declare that they don't have conflict of interest in any kind.

\section{REFERENCES}

Abdel Aziz MT, Wassef MA, Ahmed HH, Rashed L, Mahfouz S, Aly MI, Hussein RE, Abdelaziz M. (2014). The role of bone marrow derived-mesenchymal stem cells in attenuation of kidney function in rats with diabetic nephropathy. Diabetology and Metabolic Syndrome; 6(1): 34.

Abdel Aziz MT, Atta HM, Mahfouz, S, Fouad HH, Roshdy NK, Ahmed HH, Rashed LA, Sabry D, Hassouna AA, Hasan NM. (2007). Therapeutic potential of bone marrow-derived mesenchymal stem cells on experimental liver fibrosis. Clin Biochem; 40(12): 893-899.

Abdel Aziz MT, EL Asmar MF, Mostafa S, Salama H, Atta HM, Mahfouz S, Roshdy NK, Rashed LA, Sabry D, Hasan N, Mahmoud M, 
Elderwy D.(2010). Reversal of hepatic fibrosis by human $\mathrm{CD} 34^{+}$ stem/progenitor cell transplantation in rats. International Journal of Stem Cells; 3(2): 161-174.

Abdel Aziz MT, Atta HM, Roshdy NK, Rashed LA, Sabry D, Hassouna AA, Aboul Fotouh GI, Hasan NM, Younis RH, Chowdhury JR.(2012). Amelioration of murine Schistosoma mansoni induced liver fibrosis by mesenchymal stem cells. JSRM; 8(1): 28-34.

Ali G, Masoud MS. (2012). Bone marrow cells ameliorate liver fibrosis and express albumin after transplantation in $\mathrm{CCl}_{4}$-induced fibrotic liver. Saudi J Gastroenterol; 18(4): 263-267.

Crosby HA, Lalor PF, Ross E, Newsome PN, Adams DH.(2009). Adhesion of human haematopoietic $\left(\mathrm{CD} 34^{+}\right)$stem cells to human liver compartments is integrin and CD44 dependent and modulated by CXCR3 and CXCR4. J Hepatol; 51(4): 734-749.

De Coppi P, Bartsch J, Siddiqui M. (2007). Isolation of amniotic stem cell lines with potential for therapy.Nat Biotechnol; 25(5):100-106. El-Mahdi MM, Mansour WA, Hammam O, Mehana NA, Hussein TM (2014). Ameliorative effect of bone marrow-derived stem cells on injured liver of mice infected with Schistosoma mansoni. Korean J Parasitol; 52(2): 151-162.

Gressner AM, Weiskirchen R, Breitkopf K, Dooley S. (2002). Roles of TGF-beta in hepatic fibrosis. Front Biosci; 7: d793-807.

Hernandez-Gea V, Friedman SL.(2011). Pathogenesis of liver fibrosis. Annu Rev Pathol; 6: 425-456.

Hong J, Jin H, Han J, Hu H, Liu J, Li L, Huang Y, Wang D, Wu M, Qiu L, Qian Q.(2014). Infusion of human umbilical cord-derived mesenchymal stem cells effectively relieves liver cirrhosis in DEN-induced rats. Mol Med Rep; 9(4): 1103-1111.

Huang P, Gebhart N, Richelson E, Brott TG, Meschia JF, Zubair AC.(2014). Mechanism of mesenchymal stem cell-induced neuron recovery and anti-inflammation. Cytotherapy; Doi: 10.1016/j.jcyt. [Epub ahead of print]

Kehoe O, Cartwright A, Askari A, El Haj AJ, Middleton J. (2014). Intra-articular injection of mesenchymal stem cells leads to reduced inflammation and cartilage damage in murine antigen-induced arthritis. J Transl Med; 12:157. doi: 10.1186/1479-5876-12-157.

Kanazawa H, Fujimoto Y, Teratani T, Iwasaki J, Kasahara N, Negishi K, Tsuruyama T, Uemoto S, Kobayashi EY.(2011). Bone marrowderived mesenchymal stem cells ameliorate hepatic ischemia reperfusion injury in a rat model. PLoS One, 6(4): e19195. 
Li Y, Luo Y, Zhang X, Lin X, He M, Liao M. (2013). Combined taurine, epigallocatechin gallate and genistein therapy reduces HSC-T6 cell proliferation and modulates the expression of fibrogenic factors. Int $\mathbf{J}$ Mol Sci; 14(10): 20543-20554.

Li T, Yan Y, Wang B, Qian H, Zhang X, Shen L, Wang M, Zhou Y, Zhu W, Li W, Xu W.(2013). Exosomes derived from human umbilical cord mesenchymal stem cells alleviate liver fibrosis. Stem Cells and Development, 22(6): 845-854

Li Q, Zhou X, Shi Y, Li J, Zheng L, Cui L, Zhang J, Wang L, Han Z, Han Y, Fan D.(2013). In vivo tracking and comparison of the therapeutic effects of MSCs and HSCs for liver injury.; 8(4): e62363

Mannaerts I, Schroyen B, Verhulst S, Van Lommel L, Schuit F, Nyssen $M$, van Grunsven LA.(2013). Gene expression profiling of early hepatic stellate cell activation reveals a role for Igfbp3 in cell migration. PLoS One; 8(12): e84071.

Nasir GA, Mohsin S, Khan M, Shams S, Ali G, Khan SN, Riazuddin S. (2013). Mesenchymal stem cells and interleukin-6 attenuate liver fibrosis in mice. Journal of Translational Medicine, 26(11): 78-80.

Presser LD, McRae S, Waris G. (2013). Activation of TGF- $\beta 1$ promoter by hepatitis $\mathrm{C}$ virus-induced AP-1 and Sp1: role of TGF- $\beta 1$ in hepatic stellate cell activation and invasion. PLoS One; 8(2): e56367.

Puglisi MA, Tesori V, Lattanzi W, Piscaglia AC, Gasbarrini GB, D'Ugo DM, Gasbarrini A. (2011). Therapeutic implications of mesenchymal stem cells in liver injury. Journal of Biomedicine and Biotechnology; 2011: 860578 .

Radwa AM, Nihal MH, Gihan MS, Mohamed S, Magda ME, Mona KM. (2012). Transplantation of human umbilical cord blood stem cells in rabbits' fibrotic liver. Journal of American Science; 8(4): 83-94.

Sáez-Lara MJ, Frecha C, Martı'n F, Abadi'a F, Toscano M, Gil A, Fontana L.(2006). Transplantation of human $\mathrm{CD} 34^{+}$stem cells from umbilical cord blood to rats with thioacetamide-induced liver cirrhosis. Xenotransplantation; 13(6): 529-535.

Song F, Tang J, Geng R, Hu H, Zhu C, Cui W, Fan W.(2014). Comparison of the efficacy of bone marrow mononuclear cells and bone mesenchymal stem cells in the treatment of osteoarthritis in a sheep model. Int J Clin Exp Pathol; 7(4): 1415-1426.

Van Wettere AJ, Law JM, Hinton DE, Kullman SW. (2013). Anchoring hepatic gene expression with development of fibrosis and neoplasia in a toxicant-induced fish model of liver injury. Toxicol Pathol; 41(5): 744760. 
Xu H, Qian H, Zhu W, Zhang X, Yan Y, Mao F, Wang M, Xu H, Xu W.(2012). Mesenchymal stem cells relieve fibrosis of Schistosoma japonicum-induced mouse liver injury. Exp Biol Med (Maywood); 237(5): 585-592.

Zhao DC, Lei JX, Chen R, Yu WH, Zhang XM, Li SN, Xiang P. (2005). Bone marrow derived mesenchymal stem cells protect against experimental liver fibrosis in rats. World J Gastroentrol; 11(22): 34313440.

Zhao W, Li J, Cao D, Li X, Zhang L, He Y, Yue S, Wang D, Dou K.(2012). Intravenous injection of mesenchymal stem cells is effective in treating liver fibrosis. World J Gastroenterol; 18(10): 1048-1058.

Zheng L, Chu J, Shi Y, Zhou X, Tan L, Li Q, Cui L, Han Z, Han Y, Fan D. (2013). Bone marrow-derived stem cells ameliorate hepatic fibrosis by down-regulating interleukin-17. Cell and Bioscience, 3(1): 4652.

Zhou M, Qin S, Chu Y, Wang F, Chen L, Lu Y.(2014). Immunolocalization of MMP-2 and MMP-9 in human rheumatoid synovium. Int J Clin Exp Pathol; 7(6): 3048-3056..

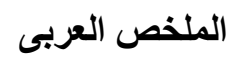

$$
\begin{aligned}
& \text { دراسة مقارنة بين آثار سى دى ؟ + + و الفئران نخاع العظام الوسيطة الخلايا الجذعية }
\end{aligned}
$$

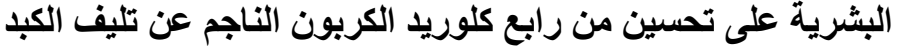

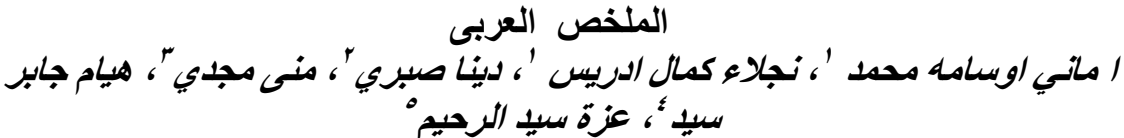

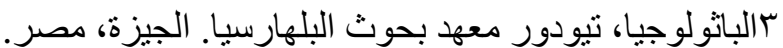

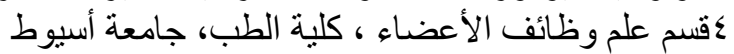

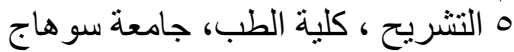

يحتوى دم الحبل السري (يو سي بي) في الإنسان و الفئر ان على خلايـا نخاع العظم الجذعية العزبة

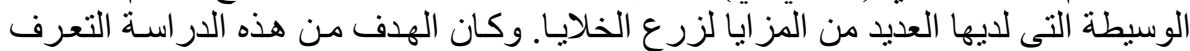

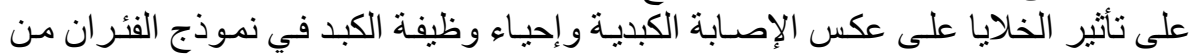

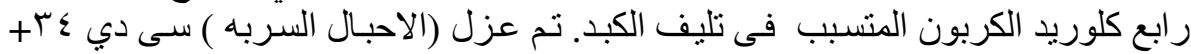

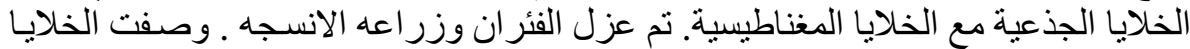

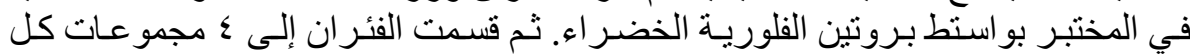

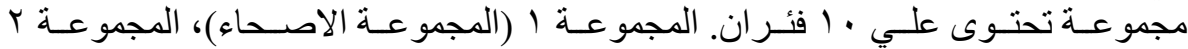

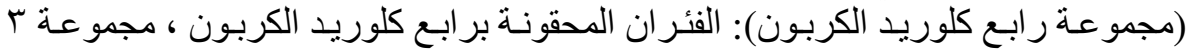




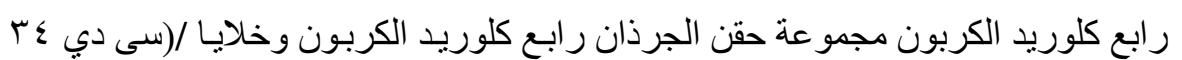

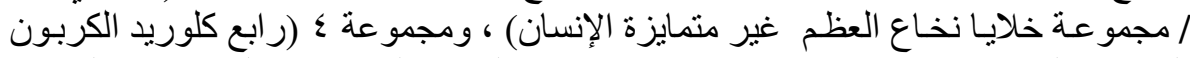

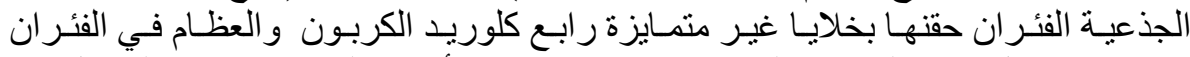

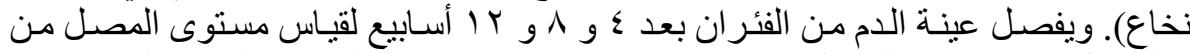

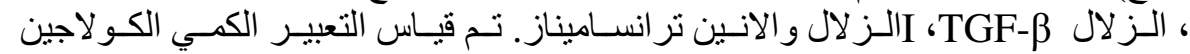

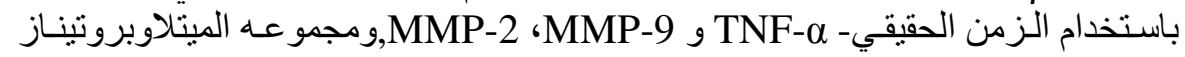

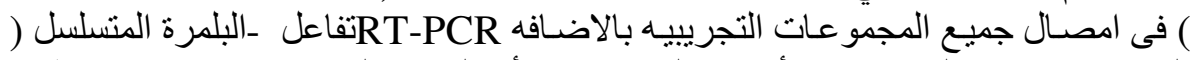

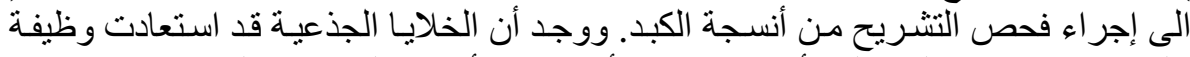

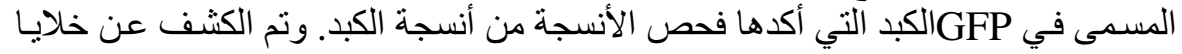

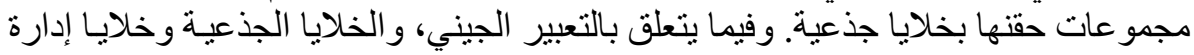

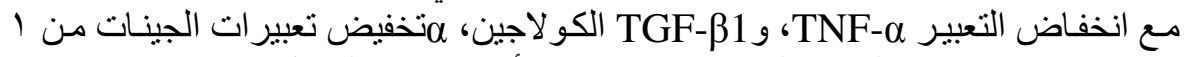

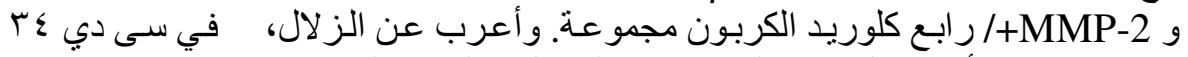

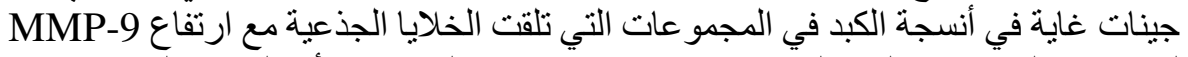

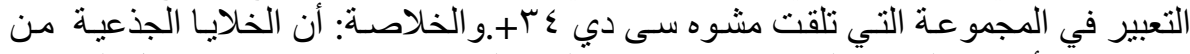

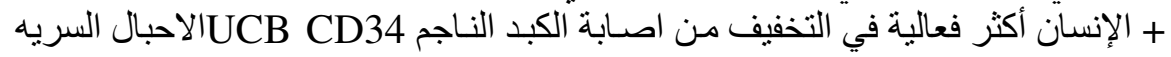

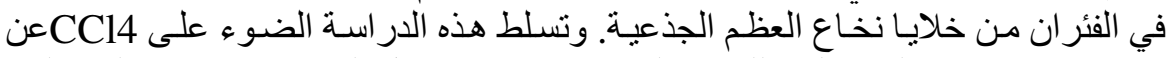

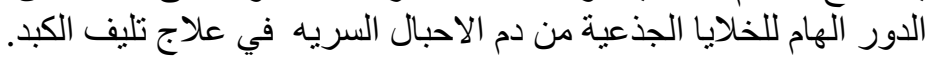

